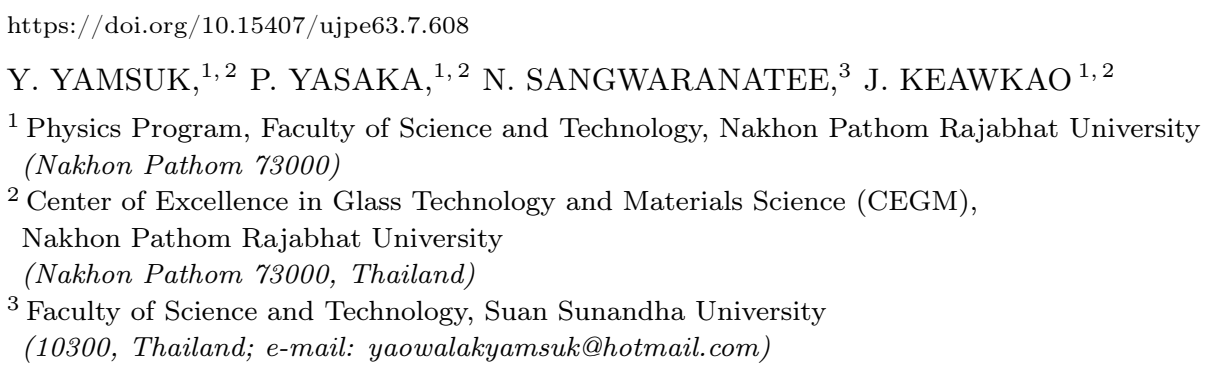

\title{
FABRICATION AND CHARACTERIZATION OF $\mathrm{Sm}^{3+}$-DOPED ZINC BARIUM BORATE GLASSES
}

\begin{abstract}
Zinc-barium-borate glasses with the composition $(60-x) \mathrm{B}_{2} \mathrm{O}_{3}-10 \mathrm{ZnO}-30 \mathrm{BaO}-x \mathrm{Sm}_{2} \mathrm{O}_{3}$ (where $x=$ 0.5, 1.0, 1.5, 2.0 and 2.5 mol \%) doped with $\mathrm{Sm}^{3+}$ ions have been prepared, and their physical and optical properties are investigated. The photoluminescence spectra recorded under the 403-nm excitation exhibited the emission bands at 564, 600, 647, and $710 \mathrm{~nm}$ corresponding to the transition ${ }^{4} G_{5 / 2} \rightarrow{ }^{6} H_{J}(J=5 / 2,7 / 2,9 / 2,11 / 2)$, respectively. The Judd-Ofelt intensity parameters $\left(\Omega_{\lambda}, \lambda=2\right.$, 4, and 6) have been evaluated, and the radiative transition probabilities, emission cross-section, and branching ratios for the excited levels of $\mathrm{Sm}^{3+}$ ions are predicted. The lifetime of the ${ }^{4} G_{5 / 2}$ level is found to decrease with an increase in the $\mathrm{Sm}^{3+}$ ion concentration.

Ke ywords: zinc-barium-borate glasses, photoluminescence, $\mathrm{Sm}^{3+}$ ion, Judd-Ofelt analysis, emission cross-section.
\end{abstract}

\section{Introduction}

Rare earth (RE) ions have been widely studied in various glasses and optical devices such as lasers, light converters, sensors, and optical fibers in the visible regions [1]. In these devices, excitations and emissions are due to transitions among $4 f$ electronic states of trivalent $\mathrm{RE}$ ions. The RE ions, $\mathrm{Sm}^{3+}$ ions, have encouraged a vast interest due to the addition of $\mathrm{Sm}^{3+}$ $\left({ }^{4} f 5\right)$ ions in the various materials in glasses. This permits one to use them for color displays and solid state light applications [2]. The excited ${ }^{4} \mathrm{G}_{5 / 2}$ level of $\mathrm{Sm}^{3+}$ ion emits in the visible region, which presents a relatively huge quantum efficiency and indicates a different quenching mechanism [3]. The glasses stimulated with $\mathrm{Sm}^{3+}$ ions emit reddish orange light as a result of the ${ }^{4} \mathrm{G}_{5 / 2} \rightarrow{ }^{6} \mathrm{H}_{J}(J=5 / 2,7 / 2,9 / 2$, $11 / 2)$ transitions. The ${ }^{4} \mathrm{G}_{5 / 2} \rightarrow{ }^{6} \mathrm{H}_{5 / 2}$ transition of the $\mathrm{Sm}^{3+}$ ions is known as a hypersensitive transition and it's liable one to increase its intensity, while there is a decrease in the luminescence site by

(C) Y. YAMSUK, P. YASAKA, N. SANGWARANATEE, J. KEAWKAO, 2018 a change in the host composition of the glass matrix [4].

Barium borate glasses possess the extensive range of applications for optoelectronic devices $[5,6]$. In particular, barium-based oxide glasses represent a high electric resistance, high refraction, low coefficient of thermal expansion, low dispersion, and relatively low melting point. Barium in glasses plays an important role as their primary network at high concentrations and a modifier at low concentrations. In addition, the barium borate glass system is of interest from a fundamental point of view due to anomalies in the compositional dependence of some physical properties $[7,8]$.

In this work, we will study the spectroscopic behavior of $\mathrm{Sm}^{3+}$ ions in the zinc-barium-borate glasses. We prepared the $\mathrm{Sm}_{2} \mathrm{O}_{3}$-doped zinc-bariumborate glasses and analyzed their physical and spectroscopic properties. We also calculated the JuddOfelt intensity parameters, by using the absorption data of the prepared glasses. The calculations were done specifically for different $\mathrm{Sm}_{2} \mathrm{O}_{3}$ concentrations. Emission properties of the glasses for dif-

ISSN 2071-0194. Ukr. J. Phys. 2018. Vol. 63, No. 7 
Table 1. Physical properties of the $\mathbf{S m}^{3+}$-doped zinc-barium-borate glasses

\begin{tabular}{|c|c|c|c|c|c|c|}
\hline Sl. No & Physical properties & $0.5 \mathrm{~mol} \%$ & $1.0 \mathrm{~mol} \%$ & $1.5 \mathrm{~mol} \%$ & $2.0 \mathrm{~mol} \%$ & $2.5 \mathrm{~mol} \%$ \\
\hline 1 & Density $\rho\left(\mathrm{g} / \mathrm{cm}^{3}\right)$ & 3.1789 & 3.2500 & 3.2502 & 3.2551 & 3.2947 \\
\hline 2 & Molar volume $\left(\mathrm{cm}^{3} / \mathrm{mol}\right)$ & 31.2328 & 31.5891 & 32.6271 & 33.6156 & 34.2374 \\
\hline 3 & Refractive index $n_{d}(589 \mathrm{~nm})$ & 1.5896 & 1.5962 & 1.5964 & 1.5969 & 1.6018 \\
\hline
\end{tabular}

ferent $\mathrm{Sm}_{2} \mathrm{O}_{3}$ concentrations are also discussed in detail.

\section{Experimental}

\subsection{Glass preparation}

The $\mathrm{Sm}^{3+}$-doped zinc-barium-borate glasses were prepared, by using chemicals such as $\mathrm{H}_{3} \mathrm{BO}_{3}, \mathrm{ZnO}$ $\mathrm{BaO}$, and $\mathrm{Sm}_{2} \mathrm{O}_{3}$. The chemical composition of the prepared glasses was $(60-x) \mathrm{B}_{2} \mathrm{O}_{3}-10 \mathrm{ZnO}-30 \mathrm{BaO}$ $x \mathrm{Sm}_{2} \mathrm{O}_{3}$ (where $x=0.5,1.0,1.5,2.0$, and $2.5 \mathrm{~mol} \%$ ) obtained by a conventional melt quenching technique. The raw materials of about $15 \mathrm{~g}$ per batch were thoroughly mixed and crushed in an agate mortar to obtain a homogeneous mixture. This mixture was taken into a porcelain crucible and kept in an electrical furnace at $1,100{ }^{\circ} \mathrm{C}$ for $3 \mathrm{~h}$. The melt was poured onto a preheated brass plate, then pressed by another graphite plate to obtain a uniform thickness. The prepared glasses were annealed for $3 \mathrm{~h}$ at $500{ }^{\circ} \mathrm{C}$ to remove strains and to improve the mechanical strength. The glasses were allowed to reach room temperature rarely and were well polished on both sides to obtain a plane faces before further optical measurements.

\subsection{Physical and optical studies}

The density of the $\mathrm{Sm}^{3+}$-doped zinc-barium-borate glasses was determined by the Archimedes method, by using a densitometer HR-200 and a weighing balance. The refractive index of the glasses was measured at room temperature, by using an Abbe refractometer at $589 \mathrm{~nm}$ with monobromo-naphthalene as a contact liquid. Physical parameters such as the density, molar volume, refractive index, and concentration of $\mathrm{Sm}^{3+}$ ions are summarized in Table 1. The optical absorption spectra of the prepared glasses were recorded on the UV-Vis-NIR regions in the range $700-1,800 \mathrm{~nm}$, by using a UV-3600 Shimadzu UV-VIS-NIR spectrophotometer. The excitation and emission spectra of the prepared glasses were

ISSN 2071-0194. Ukr. J. Phys. 2018. Vol. 63, No. 7 registered with a Cary Eclipse Fluorescence Spectrophotometer. The lifetimes of the ${ }^{4} \mathrm{G}_{5 / 2}$ excited level of $\mathrm{Sm}^{3+}$ ions were measured under the excitation at $403 \mathrm{~nm}$ by using a Cary Eclipse Fluorescence Spectrophotometer. The Judd-Ofelt intensity parameters give a significant information regarding the local structure and bonding in vicinities of $\mathrm{Sm}^{3+}$ ions that have been calculated and reported here.

\section{Results and Discussion}

\subsection{Physical properties}

Figure 1 represents a variation in the density $(\rho)$ and molar volume $\left(V_{M}\right)$ as a function of mol\% of $\mathrm{Sm}_{2} \mathrm{O}_{3}$. It is obvious from this figure that the density and molar volume of the glasses increase. An increase in the density of the prepared glasses directly correlates with the higher molecular weight of $\mathrm{Sm}_{2} \mathrm{O}_{3}$, as compared to the other constituents of the glass. The molar volumes of glasses decrease with increasing the $\mathrm{Sm}_{2} \mathrm{O}_{3}$ concentration, which reflects that the glass structure becomes more compact with increasing the concentration of $\mathrm{Sm}_{2} \mathrm{O}_{3}$. The increased molar volume is due to the higher ionic radius of $\mathrm{Sm}^{3+}$ ions $[9,10]$. The values of the density $(\rho)$ are in the range of 3.1789 to $3.2947 \mathrm{~g} / \mathrm{cm}^{3}$, while their molar volumes $\left(V_{M}\right)$ are in the range of 31.2328 to $34.2374 \mathrm{~cm}^{3} / \mathrm{mol}$.

\subsection{Absorption spectra}

Figures 2, $a$ and $b$ show the absorption spectra of $\mathrm{Sm}^{3+}$-doped zinc-barium-borate glasses, UV-vis and NIR absorption spectra in the spectral intervals 350 $600 \mathrm{~nm}$ and 700-1800 $\mathrm{nm}$ at room temperature, respectively. Several absorption bands are observed depending on the doping concentration of $\mathrm{Sm}^{3+}$. The intensities of absorption bands increase with the concentration of $\mathrm{Sm}_{2} \mathrm{O}_{3}$. The absorption spectra consisted of seven bands at 400,474, 941, 1,075, 1,220, $1,364,1,467,1,564$, and 1,586 $\mathrm{nm}$. They are assigned to the transitions ${ }^{4} \mathrm{~F}_{7 / 2},{ }^{6} \mathrm{I}_{13 / 2},{ }^{6} \mathrm{~F}_{11 / 2},{ }^{6} \mathrm{~F}_{9 / 2},{ }^{6} \mathrm{~F}_{7 / 2}$, 

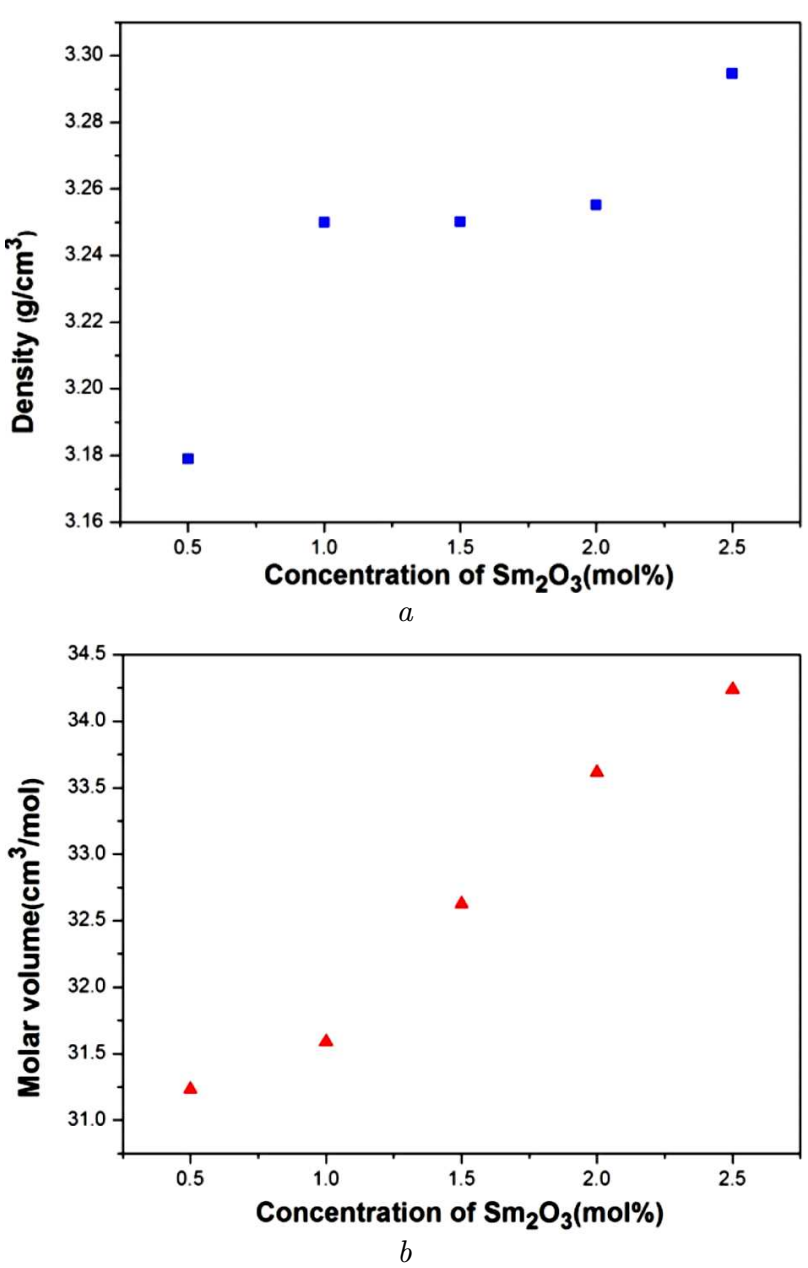

Fig. 1. Variation of the density $(\rho)$ and molar volume $\left(\mathrm{V}_{M}\right)$ for the $\mathrm{Sm}^{3+}$-doped zinc-barium-borate glasses

${ }^{6} \mathrm{~F}_{5 / 2},{ }^{6} \mathrm{~F}_{3 / 2},{ }^{6} \mathrm{H}_{15 / 2}$, and ${ }^{7} \mathrm{~F}_{1 / 2}$, respectively. Among these, the transition ${ }^{4} \mathrm{H}_{5 / 2} \rightarrow{ }^{6} \mathrm{~F}_{1 / 2}$ is the hypertensive transition of $\mathrm{Sm}^{3+}$ ions corresponding to the earlier reports $[11,12]$, which conforms the selection rule: $|\Delta S|=0,|\Delta L| \geqslant 0$ and $|\Delta j| \geqslant 0$.

\subsection{Oscillator strengths and Judd-Ofelt intensity parameters}

The Judd-Ofelt ( $\mathrm{J}-\mathrm{O}$ ) parameters are used to analyze the various radiative properties of $\mathrm{Sm}^{3+}$ ions such as the radiation transition probability, branching ratio, radiative lifetime, and stimulated emission cross-section $\left(\sigma_{r m s}\right)[13,14]$. The calculated oscillator strength $\left(f_{\text {cal }}\right)$ of an electric dipole transition from the ground state $(\psi J)$ to the excited states $\left(\psi^{\prime} J^{\prime}\right)$ of the

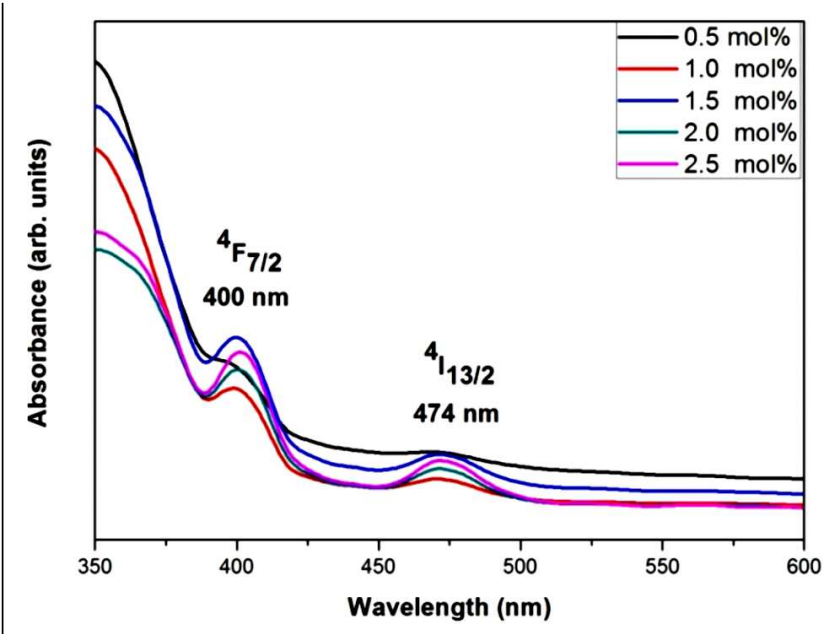

$a$

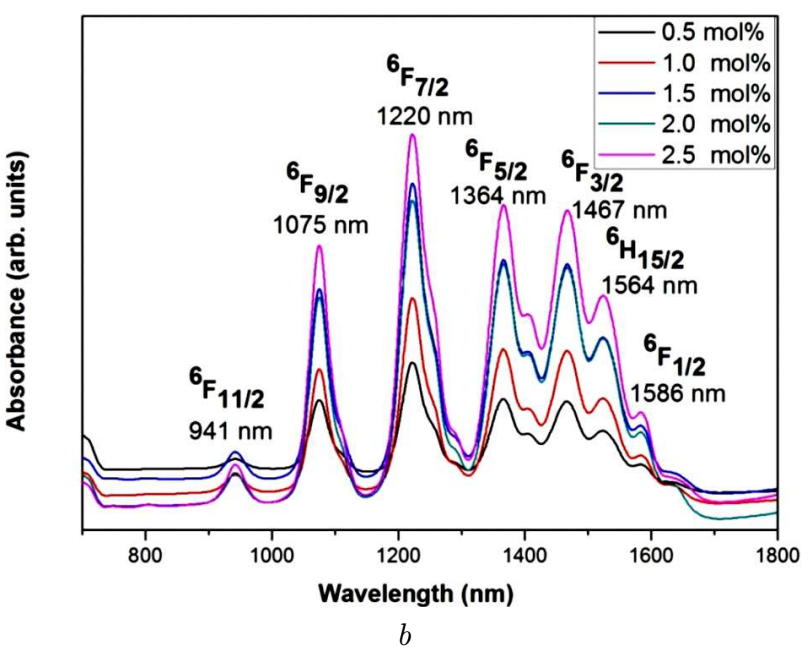

Fig. 2. UV-vis Absorption spectra of the $\mathrm{Sm}^{3+}$-doped zincbarium-borate glasses (a); NIR absorption spectra of $\mathrm{Sm}^{3+}$ doped zinc-barium-borate glasses $(b)$

$\mathrm{Sm}^{3+}$ ions in the $4 f$ configuration is estimated, by using the equation

$$
\begin{aligned}
& f_{\text {cal }}=\left[\frac{8 \pi^{2} m c v}{3 h(2 J+1)}\right]\left[\frac{\left(n^{2}+2\right)^{2}}{9 n}\right] \times \\
& \times \sum_{\lambda=2,4,6} \Omega_{\lambda}\left(\psi J\left\|U^{\lambda}\right\| \psi^{\prime} J^{\prime}\right)^{2},
\end{aligned}
$$

where $m$ is the electron mass; $\lambda$ is the mean wavelength of the observed transition, $c$ is the light velocity, $n$ is the refractive index, $h$ is Planck's constant, $\left\|\psi^{\lambda}\right\|^{2}$ are the doubly reduced square matrix elements of the unit tensor operator, which are evaluated from

ISSN 2071-0194. Ukr. J. Phys. 2018. Vol. 63, No. 7 
the intermediate coupling approximation for the transition from $\psi J$ to $\psi^{\prime} J^{\prime}[15] ;\left\langle\left\|U^{\lambda}\right\|\right\rangle$ is independent of the host matrix; and $\left(n^{2}+2\right)^{2} / 9 n$ is the Lorentz local field correction factor, which indicates that the ion is calculated in a dielectric medium but not in vacuum [16]. Integrating each absorption bands of the $\mathrm{Sm}^{3+}$ doped zinc-barium-borate glasses allows us to fit the experimental oscillator strength of the ${ }^{6} \mathrm{H}_{5 / 2}$ level to the various excited levels:

$f_{\exp }=4.318 \times 10^{-9} \int \varepsilon(v) d v$,

where $\varepsilon(v)$ is the molar extinction coefficient of the absorption band at the average energy $(v)$ in $\mathrm{cm}^{-1}$ obtained from Beer-Lambert's law. The $f_{\text {exp }}$ and $f_{\text {cal }}$ are the values for $\mathrm{Sm}^{3+}$-doped zinc-barium-borate glasses. The tabulated results show that the oscillator strength value does not vary remarkably with the increasing concentration of $\mathrm{Sm}^{3+}$ ions. The equation used to calculate the root mean square deviation (rms), $\sigma_{r m s}$, of the sample glasses is as follow:

$\sigma_{r m s}=\left[\frac{\sum\left(f_{\exp }-f_{\text {cal }}\right)^{2}}{N}\right]^{1 / 2}$,

where $N$ is the number of levels included in the fit. The total emission cross-section of $\mathrm{Sm}^{3+}$-doped zinc-barium-borate glasses is shown in Table 2. These results show the good agreement between the experimental results and calculated oscillator strengths of the glasses as compared to the $10 \mathrm{TeO}_{2}-15 \mathrm{CaO}-$ $5 \mathrm{ZnO}-10 \mathrm{Nb}_{2} \mathrm{O}_{5}-59 \mathrm{~B}_{2} \mathrm{O}_{3}-\mathrm{Sm}_{2} \mathrm{O}_{3}$ [17] and another glasses, as shown in Table. 3.

Experimental branching ratios $\left(\beta_{(R)} \exp \right)$ were calculated by the integral intensity of the emission lines starting from the given excited state and are compared with the predicted $\left(\beta_{(R)}\right.$ cal) values calculated from the $\mathrm{J}-\mathrm{O}$ theory shown in Table 2 [23]. The branching ratio is used to identify the better emission transition for the laser action. Of all the present glasses, the $0.5-\mathrm{mol} \% \mathrm{Sm}_{2} \mathrm{O}_{3}$ glass possesses the higher magnitude of branching ratio and follows the order ${ }^{4} \mathrm{G}_{5 / 2} \rightarrow{ }^{6} \mathrm{H}_{7 / 2}>{ }^{6} \mathrm{H}_{5 / 2}>{ }^{6} \mathrm{H}_{9 / 2}>{ }^{6} \mathrm{H}_{11 / 2}$. For these transitions, the experimental and calculated branching ratio values are in the intervals 0.1527 $0.1129,0.5836-0.4159,0.2439-0.0007$, and $0.01980-$ 0.7400 , respectively. It is well known that the emission transition with $\beta_{R} \geqslant 0.50$ is highly suitable for the laser emission. Among all the observed emission transitions, the ${ }^{4} \mathrm{G}_{5 / 2} \rightarrow{ }^{6} \mathrm{H}_{7 / 2}$ transition has the

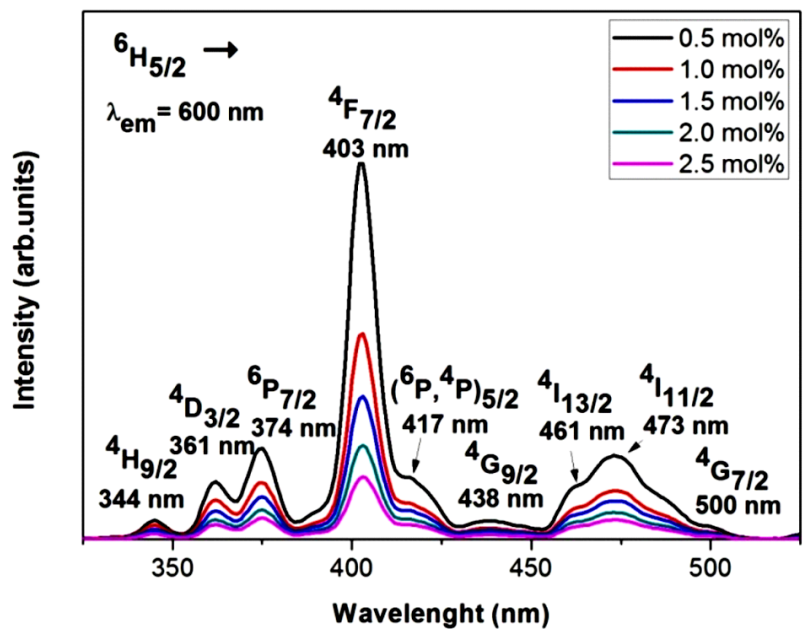

Fig. 3. Excitation spectra of $\mathrm{Sm}^{3+}$-doped zinc-barium-borate glasses as representative obtained at an emission wavelength of $600 \mathrm{~nm}$

higher value of $\beta_{R}$, and, hence, it is more suitable for the laser action.

\subsection{Excitation and emission studies}

Figure 3 displays the excitation spectra of $\mathrm{Sm}^{3+}$. doped zinc-barium-borate glasses as representative. The spectra show different excited peaks from the ground state to various excited states of the $\mathrm{Sm}^{3+}$ that obtained at an emission wavelength of $600 \mathrm{~nm}$. The peaks observed correspond to ${ }^{6} \mathrm{H}_{5 / 2} \rightarrow$ $\rightarrow{ }^{4} \mathrm{H}_{9 / 2}(344 \mathrm{~nm}),{ }^{6} \mathrm{H}_{5 / 2} \rightarrow{ }^{4} \mathrm{D}_{3 / 2}(361 \mathrm{~nm}),{ }^{6} \mathrm{H}_{5 / 2} \rightarrow$ $\rightarrow{ }^{6} \mathrm{P}_{7 / 2}(374 \mathrm{~nm}),{ }^{6} \mathrm{H}_{5 / 2} \rightarrow{ }^{4} \mathrm{~F}_{7 / 2}(403 \mathrm{~nm}),{ }^{6} \mathrm{H}_{5 / 2} \rightarrow$ $\rightarrow{ }^{6} \mathrm{P}_{5 / 2},{ }^{4} \mathrm{P}_{5 / 2}$ (417 nm), ${ }^{6} \mathrm{H}_{5 / 2} \rightarrow{ }^{4} \mathrm{G}_{9 / 2}(438 \mathrm{~nm})$, ${ }^{6} \mathrm{H}_{5 / 2} \rightarrow{ }^{4} \mathrm{I}_{13 / 2}(461 \mathrm{~nm}),{ }^{6} \mathrm{H}_{5 / 2} \rightarrow{ }^{4} \mathrm{I}_{11 / 2}$ (473 nm), and ${ }^{6} \mathrm{H}_{5 / 2} \rightarrow{ }^{4} \mathrm{G}_{7 / 2}(500 \mathrm{~nm})$. The highest peak of excitation spectra is observed at $403 \mathrm{~nm}$.

Table 2. Experimental and calculated oscillator strengths $\left(\times 10^{-6}\right)$ for $0.5 \mathrm{~mol} \%$ and the total emission cross-section of $\mathrm{Sm}^{3+}$-doped zinc-barium-borate glasses

\begin{tabular}{|c|c|c|c|c|}
\hline \multirow{2}{*}{ Transition } & \multirow{2}{*}{$\begin{array}{c}\lambda_{p} \\
(\mathrm{~nm})\end{array}$} & \multirow{2}{*}{$\begin{array}{c}\sigma_{r m s} \\
\times 10^{-22} \mathrm{~cm}^{2}\end{array}$} & \multicolumn{2}{|c|}{$\beta_{(R)}$} \\
\hline & & & Exp. & Cal. \\
\hline${ }^{4} \mathrm{G}_{5 / 2} \rightarrow{ }^{6} \mathrm{H}_{5 / 2}$ & 564 & 0.018 & 0.152684 & 0.1129 \\
\hline${ }^{4} \mathrm{G}_{5 / 2} \rightarrow{ }^{6} \mathrm{H}_{7 / 2}$ & 600 & 0.022 & 0.583637 & 0.4159 \\
\hline${ }^{4} \mathrm{G}_{5 / 2} \rightarrow{ }^{6} \mathrm{H}_{9 / 2}$ & 647 & 0.0002 & 0.243877 & 0.0007 \\
\hline${ }^{4} \mathrm{G}_{5 / 2} \rightarrow{ }^{6} \mathrm{H}_{11 / 2}$ & 710 & 6.04 & 0.019802 & 0.74 \\
\hline
\end{tabular}


Table 3. J-O intensity parameters of $\mathbf{S m}^{3+}$-doped zinc-barium-borate glasses and other reported $\mathrm{Sm}^{3+}$-doped glasses

\begin{tabular}{|c|c|c|c|c|c|}
\hline \multirow{2}{*}{ Glass } & \multicolumn{3}{|c|}{$\mathrm{J}-\mathrm{O}$ intensity parameters $\left(\times 10^{-20} \mathrm{~cm}^{2}\right)$} & \multirow{2}{*}{ Tends } & \multirow{2}{*}{ References } \\
\hline & $\Omega_{2}$ & $\Omega_{4}$ & $\Omega_{6}$ & & \\
\hline $0.5 \mathrm{~mol} \% \mathrm{Sm}_{2} \mathrm{O}_{3}$ & 1.0 & 1.88 & 1.36 & $\Omega_{4}>\Omega_{6}>\Omega_{2}$ & Present work \\
\hline TSWS10 & 0.070 & 3.048 & 2.706 & $\Omega_{4}>\Omega_{6}>\Omega_{2}$ & {$[30]$} \\
\hline Glass C & 0.92 & 2.11 & 1.29 & $\Omega_{4}>\Omega_{6}>\Omega_{2}$ & {$[31]$} \\
\hline $\mathrm{ZLiBiB}: \mathrm{Sm}^{3+}$ & 2.03 & 1.92 & 1.88 & $\Omega_{2}>\Omega_{4}>\Omega_{6}$ & [18] \\
\hline $\mathrm{Sm}^{3+}: \mathrm{CaF}_{2}-\mathrm{Bi}_{2} \mathrm{O}_{3}-\mathrm{B}_{2} \mathrm{O}_{3}$ & 15.3 & 9.09 & 9.22 & $\Omega_{2}>\Omega_{4}>\Omega_{6}$ & {$[19]$} \\
\hline $\mathrm{Sm}^{3+}: \mathrm{SFB}$ & 3.51 & 3.46 & 4.56 & $\Omega_{6}>\Omega_{2}>\Omega_{4}$ & {$[20]$} \\
\hline Bismuth borate glasses & 1.93 & 1.87 & 1.79 & $\Omega_{2}>\Omega_{4}>\Omega_{6}$ & [21] \\
\hline LCN borate & 0.84 & 4.00 & 5.02 & $\Omega_{6}>\Omega_{4}>\Omega_{2}$ & {$[22]$} \\
\hline
\end{tabular}

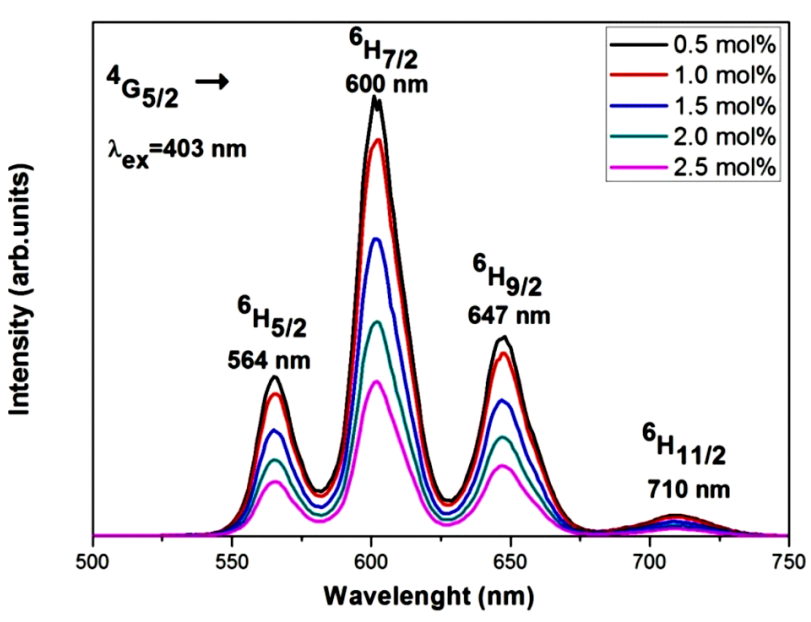

Fig. 4. Emission spectra of $\mathrm{Sm}^{3+}$-doped zinc-barium-borate glasses at an excitation wavelength of $403 \mathrm{~nm}$

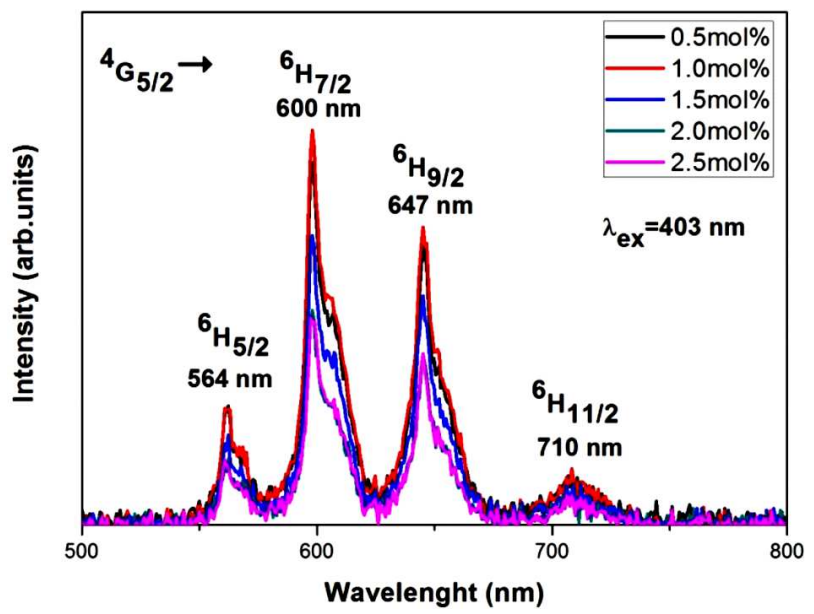

Fig. 5. X-ray luminescence spectra of $\mathrm{Sm}^{3+}$-doped zincbarium-borate glasses

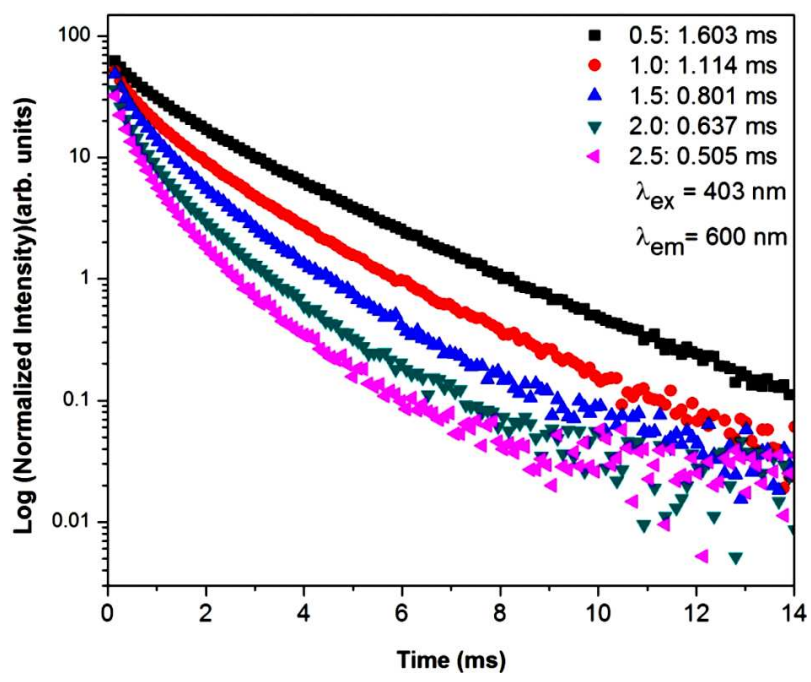

Fig. 6. Fluorescence decay profile of the ${ }^{4} \mathrm{G}_{5 / 2}$ state of a $\mathrm{Sm}^{3+}$ ion for different concentrations

Figure 4 presents the emission spectra at different concentrations in the prepared glasses at an excitation wavelength of $403 \mathrm{~nm}$. The spectra show three significant peaks along with the small peak at the longer wavelength. The observed emission peaks are centered at $564 \mathrm{~nm}, 600 \mathrm{~nm}, 647 \mathrm{~nm}$, and $710 \mathrm{~nm}$. These peaks correspond to ${ }^{4} \mathrm{G}_{5 / 2} \rightarrow{ }^{6} \mathrm{H}_{5 / 2}$, ${ }^{4} \mathrm{G}_{5 / 2} \rightarrow{ }^{6} \mathrm{H}_{7 / 2},{ }^{4} \mathrm{G}_{5 / 2} \rightarrow{ }^{6} \mathrm{H}_{9 / 2}$, and ${ }^{4} \mathrm{G}_{5 / 2} \rightarrow{ }^{6} \mathrm{H}_{11 / 2}$ transitions of the $\mathrm{Sm}^{3+}$ ions. The highest peak of emission spectra is observed at $600 \mathrm{~nm}$.

\subsection{X-ray luminescence spectra}

The X-ray luminescence spectra of $\mathrm{Sm}^{3+}$-doped zincbarium-borate glasses are shown in Fig. 5. Glass sam-

ISSN 2071-0194. Ukr. J. Phys. 2018. Vol. 63, No. 7 
ples were irradiated with X-rays $(50 \mathrm{kV}, 30 \mathrm{~mA})$. $\mathrm{Sm}^{3+}$-doped glasses have four emission peaks at 564 $\mathrm{nm}, 600 \mathrm{~nm}, 647 \mathrm{~nm}$, and $710 \mathrm{~nm}$ that are assigned to the ${ }^{4} \mathrm{G}_{5 / 2}-{ }^{6} \mathrm{H}_{5 / 2},{ }^{4} \mathrm{G}_{5 / 2}-{ }^{6} \mathrm{H}_{7 / 2},{ }^{4} \mathrm{G}_{5 / 2}-{ }^{6} \mathrm{H}_{9 / 2}$, and ${ }^{4} \mathrm{G}_{5 / 2}-{ }^{6} \mathrm{H}_{11 / 2}$ transitions [28]. The highest peak is observed at $600 \mathrm{~nm}$. Moreover, we found that the intensity for the $1.0-\mathrm{mol} \%$ sample is higher than others due to the concentration quenching effect. It can be explained by that the host material and the activator ion have different interaction mechanisms with UV and X-ray excitation. UV directly excites only the electrons of Ln ions, while X-ray excite both the electrons of Ln ions and the host. The X-ray excitation of the host glass results in the hole-electron interaction; so, the large number of secondary electrons are produced. Glass doped with $\mathrm{Sm}_{2} \mathrm{O}_{3} 1.0 \mathrm{~mol} \%$ was cut and polished to be same size and shape with commercial BGO crystals, as is shown in Fig. 5. By the total area under peaks of the spectrum, the integral scintillation efficiency of $1.0-\mathrm{mol} \% \mathrm{Sm}_{2} \mathrm{O}_{3}$-doped glass was determined and found to be $25 \%$ for a BGO scintillator crystal. Since these glasses have a long decay time of a few milliseconds, they can be used for the integration mode of scintillation in medical and industrial X-ray imagings in section systems, as well as in portal imaging systems at $\mathrm{MeV}$ energies [29].

\subsection{Decay analysis}

The lifetime of the ${ }^{4} \mathrm{G}_{5 / 2}$ energy level for the different concentrations of $\mathrm{Sm}_{2} \mathrm{O}_{3}$ was measured, and the experimental decay curves are shown in Fig. 6. As the concentration of $\mathrm{Sm}^{3+}$ ions increases, the lifetime decreases. This decrease may be due to the transfer of energy between the $\mathrm{Sm}^{3+}$ ions. The decay curves follow a single exponential function for every concentration for $\mathrm{Sm}^{3+}$-containing glasses. This may be due to the energy transfer between excited ions and groundstate ions via the cross relaxation. On the excitation of the $\mathrm{Sm}^{3+}$ ions above the ${ }^{4} \mathrm{G}_{5 / 2}$ level, the electrons decay to the ${ }^{4} \mathrm{G}_{5 / 2}$ level by the fast non-radiative relaxation, and the emission occurs from this energy level to the lower energy levels [24].

\subsection{Commission Internationale de L'Eclairage (CIE) system}

The color chromaticity of a sample is estimated, by using the Commission International de L'Eclairage (CIE) system [25, 26]. The chromaticity specifies the

ISSN 2071-0194. Ukr. J. Phys. 2018. Vol. 63, No. 7

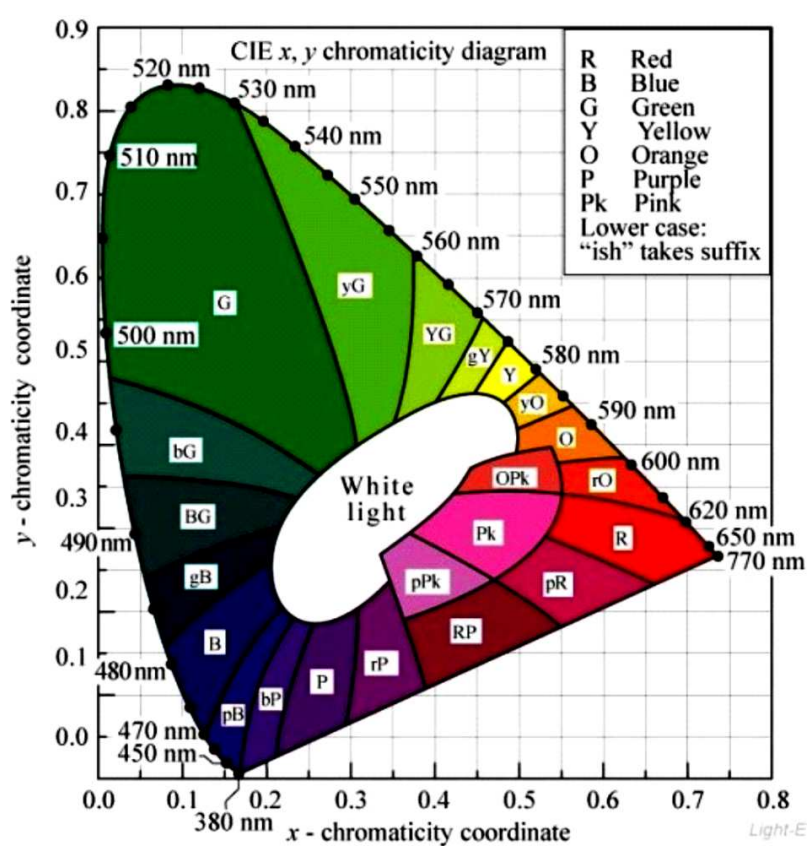

Fig. 7. CIE chromaticity diagram of $\mathrm{Sm}^{3+}$ in zinc-bariumborate glasses

hue and saturation of a color. Hence, the chromaticity coordinates can be used to determine the exact emission color and the color purity of a system [27]. Using the spectral power distribution of the glassy sample and the CIE color matching functions, the tristimulus values $(X \lambda),(Y \lambda)$, and $Z(\lambda)$ are calculated. The chromaticity co-ordinates $(x, y)$ are estimated from the tristimulus values as $x=X /(X+Y+Z)$ and $y=Y /(X+Y+Z)$. The $(x, y)$ coordinates of the present glassy system are found to be $(0.60,0.39)$, and the corresponding color of the sample is marked in the CIE chromaticity diagram in Fig. 7. The CIE diagram confirms that our novel zinc-barium-borate glassy material produces emissions in the orange region, which increases its potential for use in display applications.

\section{Conclusions}

The physical and optical properties of $\mathrm{Sm}_{2} \mathrm{O}_{3}-$ doped glasses of the composition $(60-x) \mathrm{B}_{2} \mathrm{O}_{3}-$ $10 \mathrm{ZnO}-30 \mathrm{BaO}-x \mathrm{Sm}_{2} \mathrm{O}_{3}$ are successfully studied in the present work. The density of glass samples increases with the $\mathrm{Sm}_{2} \mathrm{O}_{3}$ concentration. The molar volumes of glasses increase with the $\mathrm{Sm}_{2} \mathrm{O}_{3}$ concentration as well. The observed trend in the variation of 
the J-O parameter was $\Omega_{4}>\Omega_{6}>\Omega_{2}$. The spectroscopic quality factors for the $0.5-\mathrm{mol}_{0} \quad \mathrm{Sm}_{2} \mathrm{O}_{3}$ glasses appears to be better as compared to the other glasses in the prepared series. The emission spectra show the peaks centered at $564 \mathrm{~nm}, 600 \mathrm{~nm}$, $647 \mathrm{~nm}$, and $710 \mathrm{~nm}$. These peaks correspond to ${ }^{4} \mathrm{G}_{5 / 2} \rightarrow{ }^{6} \mathrm{H}_{5 / 2},{ }^{4} \mathrm{G}_{5 / 2} \rightarrow{ }^{6} \mathrm{H}_{7 / 2},{ }^{4} \mathrm{G}_{5 / 2} \rightarrow{ }^{6} \mathrm{H}_{9 / 2}$, and ${ }^{4} \mathrm{G}_{5 / 2} \rightarrow{ }^{6} \mathrm{H}_{11 / 2}$ transitions of the $\mathrm{Sm}^{3+}$ ions. The concentration quenching behavior was observed due to the increasing number of $\mathrm{Sm}^{3+}$ ions in the glass matrix. The lifetime values corresponding to the ${ }^{4} \mathrm{G}_{5 / 2}$ excited state are found to decrease with an increase in the $\mathrm{Sm}^{3+}$ ion concentration. The CIE 1931 chromaticity co-ordinates $(0.60,0.39)$ are also calculated to confirm the potential of the produced materials for the use in optical devices.

The authors would like to thank the Center of Excellence in Glass Technology and Materials Science (CEGM), Faculty of Science and Technology, Nakhon Pathom Rajabhat University for instruments and facilities. The thanks are also due to the Research and Development Institute, NPRU, for facilities.

1. A. Kitai. Luminescent Materials and Applications (Wiley, 2008).

2. Ch. S. Rao, C.K. Jayasankar. Spectroscopic and radiative properties of $\mathrm{Sm}^{3+}$-doped $\mathrm{K}-\mathrm{Mg}-\mathrm{Al}$ phosphate glasses. Opt. Commun. 286, 204 (2013).

3. S. Shanmuga Sundari, K. Marimuthu, M. Sivraman, S. Surendra Babu. Composition dependent structural and optical properties of $\mathrm{Sm}^{3+}$-doped sodium borate and sodium fluoroborate glasses. J. Lumin. 130, 1313 (2010).

4. A. Patra, D. Kundu, D. Gunguli. A study of the structural evolution of the sol-gel derived $\mathrm{Sm}^{3+}$-doped silica glass. Mater. Lett. 32, 43 (1997).

5. R.S. Kaundal, S. Kaur, N. Singh, K.J. Singh. Investigation of structural properties of lead strontium borate glasses for gamma-ray shielding applications. J. Phys. Chem. Solids 71, 1191 (2010).

6. B. Bhatia, V. Parihar, S. Singh, A.S. Verma. Spectroscopic properties of $\mathrm{Pr}^{3+}$ in lithium bismuth borate glasses. Am. J. Condens. Matter. Phys. 3, 80 (2013).

7. H.A. El-Batal, A.M. Abdelghany, N.A. Ghoneim, F.H. ElBatal. Effect of 3d-transition metal doping on the shielding behavior of barium borate glasses: a spectroscopic study. Spectrochim. Acta Part A Mol. Biomol. Spectrosc. 133, 534 (2014).

8. A.M. Abdelghany, A.H. Hammad. Impact of vanadium ions in barium borate glass. Spectrochim. Acta Part A. Mol. Bimol. Spectrosc. 137, 39 (2015).

\section{4}

9. D.D. Ramteke, Vijay Kumar, H.C. Swart. Spectroscopic studies of $\mathrm{Sm}^{+} / \mathrm{Dy}^{+}$co-doped lithium boro-silicate glasses. J. Non-Cryst. Solids 438, 49 (2016).

10. D.D. Ramteke, H.C. Swart, R.S. Gedam. Spectroscopic properties of $\operatorname{Pr} 3+$ ions embedded in lithium borate glasses. Phys. B Condens. Matter 480, 111 (2016).

11. C.R. Kesavulu, C.K. Jayasankar. Spectroscopic properties of $\mathrm{Sm}^{3+}$ ions in lead fluorophosphate glasses. J. Lumin. 132, 2802 (2012).

12. A. Mohan Babu, B.C. Jamalaiah, T. Sasikala, S.A. Saleem, L. Rama Moorthy. Absorption and emission spectral studies of $\mathrm{Sm}^{3+}$-doped lead tungstate tellurite glasses. J. Alloy. Compd. 509, 4743 (2011).

13. B.R. Judd. Optical absorption intensities of rare-earth ions. Phys. Rev. 127, 750 (1962).

14. G.S. Ofelt. Intensities of crystal spectra of rare-earth ions. J. Chem. Phys. 37, 511 (1962).

15. M. Jayasimhadri, L.R. Moorthy, S.A. Saleem, R.V.S.S.N. Ravikumar. Spectroscopic characteristics of $\mathrm{Sm}^{3+}$-doped alkali fluorophosphate glasses. Spectrochim. Acta A 64, 939 (2006).

16. W.T. Carnall, H. Crosswhite, H.M. Crosswhite. Energy level structure and transition probabilities of the trivalent lanthanides in LaF3. Argonne National Laboratory. Report ANL-78-XX-95.

17. O. Ravi, C. Madhukar Reddy, L. Monoj, B. Deva Prasad Raju. Structural and optical studies of $\mathrm{Sm}^{3+}$ ions doped niobium borotellurite glasses J. Mol. Struct. 1029, 53 (2012).

18. M.B. Reddy, S. Sailaja, P. Giridhar, C.N. Raju, B.S. Reddy. Spectroscopic investigations of $\mathrm{Sm}^{3+}$ ions doped $\mathrm{B}_{2} \mathrm{O}_{3}-\mathrm{Bi}_{2} \mathrm{O}_{3}-\mathrm{ZnO}-\mathrm{Li}_{2} \mathrm{O}$ glasses. Ferroelectr. Lett. 38, 40 (2011).

19. A.A. Ali. Optical properties of $\mathrm{Sm}^{3+}$-doped. $\mathrm{CaF}_{2}$ bismuth borate glasses. J. Lumin. 129, 1314 (2009).

20. D. Umamaheswari, B.C. Jamalaiah, T. Sasikala, L. IIGon Kim, Rama Moorthy. Photoluminescence properties of $\mathrm{Sm}^{3+}$-doped SFB glasses for efficient visible lasers. J. Non-Cryst. Solids 358, 782 (2012).

21. A. Agarwal, I. Pal, S. Singhi, M.P. Aggarwal. Judd-Ofelt parameters and radiative properties of $\mathrm{Sm}^{3+}$ ions doped zinc bismuth borate glasses Opt. Mater. 32, 339 (2009).

22. Y.C. Ratnakaram, N.D. Thirpathi, R.P.S. Chakaradhar. Spectral studies of $\mathrm{Sm}^{3+}$ and $\mathrm{Dy}^{3+}$ doped lithium cesium mixed alkali borate glasses J. Non-Cryst. Solids 352, 3914 (2006).

23. Phan Van Do, V.u. Phi Tuyen, Vu Xuan Quang, Nguyen Trong Thanh, Vu Thi Thai Ha, Nicholas M. Khaidukov, Yong-Ill Lee, B.T. Huy. Judd-Ofelt analysis of spectroscopic properties of $\mathrm{Sm}^{3+}$ ions in $\mathrm{K}_{2} \mathrm{YF}_{5}$ crystal. J. Alloys Compd. 520, 262 (2012).

24. T. Suhasini, J. Suresh Kumar, T. Sasikala, K. Jang, H.S. Lee, M. Jayasimhadri,J.H. Jeong, S.S. Yi, L.R. Moorthy. Absorption and fluorescence properties of $\mathrm{Sm}^{3+}$ ions in fluoride containing phosphate glasses. Opt. Mater. 31, 1167 (2009).

ISSN 2071-0194. Ukr. J. Phys. 2018. Vol. 63, No. 7 
25. R.G. Abhilash Kumar, Satoshi Hata, Ken-ichilkeda, K.G. Gopchandran. Influence of metal ion concentration in the glycol mediated synthesis of $\mathrm{Gd}_{2} \mathrm{O}_{3}: \mathrm{Eu}^{3+}$ nanophosphor. Ceramics Intern. 40, 2915 (2014).

26. G. Vimal, P. Mani Kamal, P.R. Biju, Joseph Cyriac, N.V. Unnikrishnan, M.A. Ittyachen. Synthesis, structural and spectroscopic investigations of nanostructured samarium oxalate crystals. Spectrochim. Acta A: Molec. Biomolec. Spectrosc. 122, 624 (2014).

27. P.K. Kaiser. Res. Meth. Instrum. 6 (5) 473 (1974).

28. G. Lakshminarayana, Rong Yang, Mengfei Mao, Jianrong Qiu. Spectral analysis of $\mathrm{RE}^{3+}(\mathrm{RE}=\mathrm{Sm}, \mathrm{Dy}$, and $\mathrm{Tm})$ : $\mathrm{P}_{2} \mathrm{O}_{5}-\mathrm{Al}_{2} \mathrm{O}_{3}-\mathrm{Na}_{2} \mathrm{O}$ glasses. Opt. Mater. 31, 1506 (2009).

29. N. Wantana, S. Kaewjaeng, S. Kothan, H.J. Kim, J. Kaewkhao. Energy transfer from $\mathrm{Gd}^{3+}$ to $\mathrm{Sm}^{3+}$ and luminescence characteristics of $\mathrm{CaO}-\mathrm{Gd}_{2} \mathrm{O}_{3}-\mathrm{SiO}_{2}-\mathrm{B}_{2} \mathrm{O}_{3}$ scintillating glasses. J. Lumin. 181, 382 (2017).

30. V. Himamaheswara Rao, P. Syam Prasad, M. Mohan Babu, P. Venkateswara Rao, Luís F. Santos, G. Naga Raju, $\mathrm{N}$. Veeraiah. Luminescence properties of $\mathrm{Sm}^{3+}$ ions doped heavy metal oxide tellurite-tungstate-antimonate glasses. Ceramics Inter. 43, 16467 (2017).
31. A.S. Rao Nisha Deopa. Spectroscopic studies of $\mathrm{Sm}^{3+}$ ions activated lithium lead alumino borate glasses for visible luminescent device applications. Opt. Mater. 72, 31 (2017).

Received 28.05.18

І. Ямсук, П. Ясака, Н. Сангваранаті, Дж. Ківкао

ВИГОТОВЛЕННЯ І ХАРАКТЕРИСТИКА СТЕКОЛ З БОРАТІВ ЦИНКУ І БАРІЮ, ДОПОВАНИХ $\mathrm{Sm}^{3+}$

$\mathrm{P}$ е $з$ ю м е

Виготовлено скло з боратів цинку і барію складу (60$-x) \mathrm{B}_{2} \mathrm{O}_{3}-10 \mathrm{ZnO}-30 \mathrm{BaO}-x \mathrm{Sm}_{2} \mathrm{O}_{3}$ (де $x=0,5,1,0,1,5,2.0$ та 2,5 моль\%), допованих іонами $\mathrm{Sm}^{3+}$ і вивчено їх фізичні та оптичні властивості. Спектри фотолюмінесценції, виміряні після збудження на 403 нм, містять смуги емісії на 564, 600, 647 та $710 \mathrm{Hм}$, відповідні переходам ${ }^{4} \mathrm{G}_{5 / 2} \rightarrow{ }^{6} \mathrm{H}_{J}(J=5 / 2$, $7 / 2,9 / 2,11 / 2)$, відповідно. Оцінені Джадд-Офельта параметри інтенсивності $\left(\Omega_{\lambda}, \lambda=2,4\right.$ і 6$)$ і передбачені ймовірності радіаційних переходів, перетин емісії, коефіцієнти розпаду збуджених рівнів іона $\mathrm{Sm}^{3+}$. Виявлено зменшення часу життя рівня ${ }^{4} \mathrm{G}_{5 / 2}$ при збільшенні концентрації $\mathrm{Sm}^{3+}$ іонів. 